\title{
Morphological and functional aspects of oxytetracycline administration to conventional rats
}

\author{
By E. J. RUI'TENBERG, E. H. KAMPELMACHER, \\ LUCRETIA M. vaN NOORLE JANSEN AND Ph. COHEN \\ National Institute for Public Health, Bitthoven, The Netherlands \\ (Received 20 December 1971-Accepted 5 March 1973)
}

\begin{abstract}
I. Studies were performed with female rats to examine the effect of various levels of orally administered oxytetracycline on body-weight, weight of various portions of the intestinal tract, weight of mesenteric lymph nodes, distribution pattern of the tissue elements in the terminal portion of the ileum, and on the susceptibility to invasion by Salmonella typhi-murium.

2. There was no growth promotion resulting from any antibiotic treatment. A consistent finding was the decrease in the wet weight of mesenteric lymph nodes in the rats given antibiotic.

3. In the bacteriological test, no differences between antibiotic-fed and control groups were observed in isolations from the liver, spleen or intestinal tissue. It was concluded that there were no effects of oxytetracycline administration on invasive capacity of orally administered $S$. typhi-murium.
\end{abstract}

Antibiotics are widely used as growth-promoting agents in diets for farm animals, especially for pigs, chickens and calves (Braude, Kon \& Porter, I955; Coates, 1962; Tangl, 1964; Franti, Alder \& Julian, 1971).

Besides promoting growth, other effects in the treated animals have been observed. Of particular interest is the observation made by many authors (Clegg, 1962) that a low level of antibiotics in the diet produces a decrease in weight of the small intestine. This effect might possibly result from quantitative or qualitative changes in the intestinal microflora. By analogy with germ-free animals which, compared with their conventional counterparts, show morphological differences in the intestinal tract (Gordon, I960), it is conceivable that a reduction in the microbial flora could cause alterations in the tissues of the small intestine. Little is known about the effects of such changes on intestinal function in farm animals, but it is possible that in animals given dietary supplements of antibiotics the intestinal tissue and other viscera might show increased susceptibility to invasion by pathogenic micro-organisms such as Salmonella spp.

The work described was an attempt to establish a laboratory model with rats to study the effects of dietary antibiotics on the morphological characteristics and function of the intestinal tract and the associated lymph nodes. Various levels of antibiotic supplementation were used. According to present farming practice, they may be described as growth-promoting (up to $20 \mathrm{mg} / \mathrm{kg}$ diet), prophylactic (20-100 $\mathrm{mg} / \mathrm{kg}$ diet), and therapeutic (over Ioo $\mathrm{mg} / \mathrm{kg}$ diet). 
EXPERIMENTAL

\section{Animals}

Female conventional rats (Wistar strain) of various ages (see Table r), purchased from the Central Institute for the Breeding of Laboratory Animals, were used. They were kept individually in wire-cages and given water and feed $a d$ lib. The diet was composed of (g) wheat meal 2000 , milk powder I $_{000}, \mathrm{NaCl}_{1}, \mathrm{CaCO}_{3}$ I 5 . No vitamins or any other supplements were included in the diet. The feed was bacteriologically examined at regular intervals. In nearly all instances the examination revealed Enterobacteriaceae (an average of $\mathrm{IO}^{2} / \mathrm{g}$ ) but no salmonellas.

\section{Administration of antibiotic}

Oxytetracycline in the form of TM Io, containing $22 \mathrm{~g}$ oxytetracycline/kg (Pfizer, Rotterdam, The Netherlands), was added to the diet to supply $20,92 \cdot 5,275$ and $55^{\circ}$ mg oxytetracycline/kg diet. The required quantity was weighed on a milligram balance and mixed with a small amount of well-dried diet in a sterile mortar and finally homogenized with the remaining diet. The diet containing TM ro was stored in a desiccator over silica gel to preserve the activity of the antibiotic. The diets were freshly prepared every 3-4 weeks. Microbiological control on the activity of oxytetracycline wa carried out regularly.

\section{Morphological examination}

At the end of the experimental period, the animals were weighed, killed by carbon dioxide asphyxiation, and the small intestine part I (i.e. proximal half), small intestine part II (i.e. distal half) and caecum with and without contents were dissected out and their fresh weight and dried weight after drying in the incubator $\left(90^{\circ}\right)$ overnight were determined. Only the fresh weight of mesenteric lymph nodes was recorded. All values were expressed in $\mathrm{mg} / \mathrm{g}$ body-weight.

For histological examination of the small intestine a $10 \mathrm{~mm}$ portion of the caudal end (ileum section) was fixed in Bouin's fluid. The remaining part of the small intestine was divided into a proximal and distal half to determine the weight as described above. From the fixed tissues serial cross-sections were made and stained by Masson's haematoxylin-erythrosin-safranin method (Romeis, I948). This procedure allows the submucosa to be demonstrated easily (collagen is stained brightly golden-yellow), and the general morphological fcatures of the small intestine can be studied as well. The nuclear staining is very distinct; cytoplasm is reddish; muscle, nerve and elastic fibres are bright red.

For histometrical analysis, sections I, 26 and 51 were selected. For this purpose, the 'random shot' method developed by Chalkley (1943-4) and Strehler, Mark, Mildvan \& Gee (1959) was used. A grid of 400 intersections was superimposed on the microscopic field including the entire width of the intestinal wall. Three areas were selected at random from each microscopic preparation. The results were expressed as ratios of the intestinal wall occupied by the tissue element measured namely (I) serosa 
and muscularis, (2) submucosa, (3) lamina propria (the part of the mucosa between muscularis mucosae and villi), (4) villus (epithelium and stroma), and (5) mucosa (combined values of lamina propria and villus).

\section{Test for resistance to bacterial invasion}

To test the ability of the intestine to resist invasion by pathogens, spleen, liver and intestinal tract were examined for the presence of Salmonella after oral inoculation with $S$. typhi-murium. The strain used was $S$. typhi-murium $\mathrm{C} 9595 / 63$, isolated from a pig. The freeze-dried strain was stored in vials at room temperature. The contents of a vial were cultured in $30 \mathrm{ml}$ beef broth at $37^{\circ}$ for $18 \mathrm{~h}$. The culture was then spread on an agar-agar plate, and from one detached colony a sample was used to inoculate another flask of $30 \mathrm{ml}$ beef broth. Previous experiments have shown that after $18 \mathrm{~h}$ incubation at $37^{\circ}$ such a culture contains $\mathrm{I} \cdot 3-\mathrm{I} \cdot 5 \times 10^{9}$ bacteria $/ \mathrm{ml}$.

The culture $(0 . \mathrm{I} \mathrm{ml})$ was introduced into the pharynx of all animals by means of a blunt needle (Ruitenberg, Kampelmacher \& Noorle Jansen, 1972a).

The animals were killed by carbon dioxide asphyxiation and the intestinal tract, spleen and liver were examined for the presence of Salmonella 4 and $8 \mathrm{~h}$ after administration of the bacteria. At $4 \mathrm{~h}$ the effect of a possible alteration in the intestinal tract with regard to the penetration of salmonellas could be studied, and at $8 \mathrm{~h}$ the effect of a change in the multiplication of salmonellas due to a possible alteration in the intestinal flora could also be investigated (Ruitenberg, Guinée, Kruyt \& Berkvens, 1971). For bacteriological examination the entire spleen and the caudate lobe of the liver were excised and cultured in $6 \mathrm{ml}$ beef broth. A length of duodenum about Io $\mathrm{mm}$ from the pylorus, a $100 \mathrm{~mm}$ segment of the ileum, the distal one-third of the caecum and the 1 cctum, with contents, were cut up finely and placed in four tubes with Io $\mathrm{ml}$ Muller-Kauffmann tetrathionate broth. The media were incubated at $37^{\circ}$ and after 24 and $48 \mathrm{~h}$ incubation spread on brilliant green-phenol red agar-agar plates $140 \mathrm{~mm}$ in diameter. Suspected colonies from these plates were submitted to the usual biochemical and serological examinations (Guinée, Kampelmacher, Hofstra \& Keulen, 1964).

\section{Statistical analysis}

For the statistical evaluation of the results obtained from the morphological studies Student's $t$ test was used. Before the experiments were performed we decided that any effect of antibiotic treatment would be a decrease in the criteria tested and we therefore used one-sided tests of significance.

\section{Experimental design}

Fourteen experiments were carried out and details of each experiment are given in Table I.

\section{RESULTS}

\section{Body-weights and morphological examination}

Expts $\mathrm{I}(a)$ and $\mathrm{I}(b)$ (control groups). We deduce from the results for these experiments that the standard deviation of the individual values in relation to the mean value 
Table I. Design of experiments in which the effect of various oral dosages of oxytetracycline were studied in female conventional rats. In each experiment, a similar number of controls were used

\begin{tabular}{|c|c|c|c|c|c|c|c|c|c|c|}
\hline \multirow[b]{3}{*}{$\begin{array}{l}\text { Expt. } \\
\text { no. }\end{array}$} & \multirow{2}{*}{\multicolumn{2}{|c|}{ Animals }} & \multirow{2}{*}{\multicolumn{2}{|c|}{$\begin{array}{l}\text { Oxytetracycline } \\
\text { treatment }\end{array}$}} & \multicolumn{2}{|c|}{ Body tissue wts } & \multicolumn{2}{|c|}{$\begin{array}{l}\text { Examination of } \\
\text { various tissues }\end{array}$} & \multicolumn{2}{|c|}{$\begin{array}{l}\text { Bacteriology } \\
\text { function test - } \\
\text { inoculation of } \\
10^{8} S \text {. typhi- } \\
\text { murium }\end{array}$} \\
\hline & & & & & Weekly & & & Histo- & $4 \mathrm{~h}$ after & $8 \mathrm{~h}$ after \\
\hline & No. & $\begin{array}{l}\text { Wt (g) or } \\
\text { age (d) }\end{array}$ & $\begin{array}{c}(\mathrm{mg} / \mathrm{kg} \\
\text { diet })\end{array}$ & $\begin{array}{r}\text { Period } \\
\text { (weeks) }\end{array}$ & $\begin{array}{l}\text { during } \\
\text { life }\end{array}$ & $\begin{array}{l}\text { After } \\
\text { death }\end{array}$ & $\mathrm{Wt}$ & $\begin{array}{l}\text { metrical } \\
\text { analysis }\end{array}$ & $\begin{array}{l}\text { inocu- } \\
\text { lation }\end{array}$ & $\begin{array}{l}\text { inocu- } \\
\text { lation }\end{array}$ \\
\hline $\mathrm{I}(a)$ & $I 2+I I$ & $30-35 \mathrm{~g}$ & 0 & 4 & $t$ & + & + & - & - & - \\
\hline I $(b)$ & $13+12$ & $30-35 \mathrm{~g}$ & 0 & 8 & + & + & $t$ & - & - & - \\
\hline 2 & IO & $2 \mathrm{~d}-23 \mathrm{~d}$ & 20 & 4 & - & + & + & - & - & - \\
\hline 3 & 12 & $2 \mathrm{r}-23 \mathrm{~d}$ & 20 & 8 & - & + & + & - & - & - \\
\hline 4 & 12 & $2 \mathrm{I}-23 \mathrm{~d}$ & 20 & 12 & + & + & + & - & - & - \\
\hline 5 & 13 & $2 \mathrm{I}-23 \mathrm{~d}$ & 20 & 16 & + & + & + & - & - & - \\
\hline 6 & $4+7$ & od & $92 \cdot 5$ & $7 \mathrm{I}$ & - & + & + & - & - & - \\
\hline 7 & $2 \times 10$ & $30-35 \mathrm{~g}$ & 275 & 6 & - & - & - & - & + & + \\
\hline 8 & $2 \times 10$ & $3^{\circ}-35 \mathrm{~g}$ & 275 & 14 & - & - & - & - & + & + \\
\hline 9 & $2 \times 10$ & $30-35 \mathrm{~g}$ & 275 & 22 & - & - & - & - & + & + \\
\hline I0 & $2 \times 10$ & $30-35 \mathrm{~g}$ & 275 & 34 & - & + & - & - & + & + \\
\hline I I & $2 \times 10$ & $3^{0}-35 \mathrm{~g}$ & 275 & 46 & - & + & - & - & + & + \\
\hline I2 & I I & $3^{0}-35 \mathrm{~g}$ & 275 & $9 I$ & - & + & + & + & - & - \\
\hline I 3 & $2 \times 10$ & $3^{0}-35 \mathrm{~g}$ & 550 & 24 & - & + & - & - & + & + \\
\hline I 4 & 12 & $30-35 \mathrm{~g}$ & 550 & 85 & - & + & + & - & - & - \\
\hline
\end{tabular}

was small enough to expect that the effect of an oxytetracycline treatment could yield statistically significant differences indicating that both the experimental animal and the methods used were suitable for the present study.

Expts 2-5 (groups to which a low level of oxytetracycline (20 $\mathrm{mg} / \mathrm{kg}$ ) was administered). No significant difference in body-weight between oxytetracycline-fed animals and controls could be found; thus no growth-promoting effect of oxytetracycline was observed. Similarly, there was no effect of antibiotic treatment on the weight of the tissues of the intestinal tract.

The only tissue in which an influence of the antibiotic treatment was observed was the mesenteric lymph nodes. A statistically significant decrease in the weight of the mesenteric lymph node was seen after oxytetracycline feeding for 8,12 and 16 weeks (see Table 2). The decrease in wet weight of the mesenteric lymph nodes was most marked at 12 weeks after administration began.

Expt 6 (group to which a prophylactic level of oxytetracycline $(92.5 \mathrm{mg} / \mathrm{kg}$ ) was administered). The results were subjected to statistical analysis, although the control and experimental group consisted of only a small number of animals. The differences between the two groups of rats did not suggest an effect of oxytetracycline administration.

During the first 4 weeks the weights of the animals were slightly decreased. Subsequently the weights of the animals included in the experiment were similar to those 
Table 2. Effect of various dose levels of oxytetracycline, administered in the diet, on the wet weight of mesenteric lymph nodes of female rats

\begin{tabular}{|c|c|c|c|c|c|c|c|c|}
\hline & & & & & & Mean weight 0 & & \\
\hline & & nals & $\begin{array}{r}\text { Oxycet } \\
\text { trea }\end{array}$ & cycint & & & Mesenteric & Standard \\
\hline Expt no. & No. & $\begin{array}{l}\text { Wt (g) or } \\
\text { age (d) }\end{array}$ & $\underset{\text { diet }}{\mathrm{mg} / \mathrm{kg}}$ & $\begin{array}{c}\text { Period } \\
\text { (weeks) }\end{array}$ & $\begin{array}{l}\text { Body } \\
\text { (g) }\end{array}$ & $\begin{array}{l}\text { lymph nodes } \\
\text { (mg) }\end{array}$ & $\begin{array}{c}(\mathrm{mg} / \mathrm{g} \\
\text { body-wt) }\end{array}$ & $\begin{array}{l}\text { of the } \\
\text { mean }\end{array}$ \\
\hline I $(a)$ & 12 & $30-35 \mathrm{~g}$ & $\circ$ & 4 & I I $6 \cdot 9$ & $143 \cdot 3$ & $I \cdot 24$ & 0.09 \\
\hline & I I & $3^{0-}-35 \mathrm{~g}$ & 0 & 4 & $123 \cdot 7$ & 126.7 & $1 \cdot 02$ & 0.04 \\
\hline $\mathrm{I}(b)$ & I3 & $30-35 \mathrm{~g}$ & 0 & 8 & $\times 57.5$ & I $24 \cdot 3$ & 0.80 & 0.08 \\
\hline & 12 & $30-35 \mathrm{~g}$ & $\circ$ & 8 & I 66.2 & $108 \cdot 3$ & 0.65 & 0.04 \\
\hline 2 & Io & $2 \mathrm{I}-23 \mathrm{~d}$ & o & 4 & $96 \cdot 7$ & $6 I \cdot 0$ & 0.63 & 0.05 \\
\hline & IO & $21-23 d$ & 20 & 4 & 102.0 & $52 \cdot 2$ & 0.51 & 0.09 \\
\hline 3 & I 3 & $2 \mathrm{I}-23 \mathrm{~d}$ & 0 & 8 & 144.0 & 104.6 & 0.73 & 0.05 \\
\hline 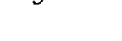 & 12 & $2 \mathrm{I}-23 \mathrm{~d}$ & 20 & 8 & $13 \mathrm{I} \cdot 0$ & $62 \cdot 5$ & $0.50^{*}$ & 0.04 \\
\hline 4 & 12 & $2 \mathrm{I}-23 \mathrm{~d}$ & o & 12 & $192 \cdot 1$ & 193.3 & $I \cdot 06$ & 0.09 \\
\hline & 12 & $2 I-23 d$ & 20 & 12 & I 89.8 & I I $4: 2$ & $0.60^{*}$ & 0.03 \\
\hline 5 & 13 & $2 \mathrm{I}-23 \mathrm{~d}$ & 0 & I6 & $217 \cdot 5$ & $98 \cdot 9$ & 0.70 & 0.03 \\
\hline & 13 & $2 \mathrm{I}-23 \mathrm{~d}$ & 20 & т6 & $200 \% 4$ & $88 \cdot 5$ & $0.59^{*}$ & 0.03 \\
\hline 6 & 7 & od & o & 71 & $272 \cdot 7$ & $132 \cdot 1$ & 0.50 & 0.06 \\
\hline & 4 & $O d$ & $92 \cdot 5$ & 71 & 310.5 & $155^{\circ} 0$ & 0.51 & 0.18 \\
\hline 12 & I I & $30-35 \mathrm{~g}$ & 0 & $9 \mathrm{I}$ & $263 \cdot 6$ & 100.9 & 0.61 & 0.02 \\
\hline & I I & $30-35 \mathrm{~g}$ & 275 & 91 & $249^{\circ} 9$ & I $57 \cdot 3$ & $0.40^{*}$ & 0.02 \\
\hline I 4 & I I & $30-35 \mathrm{~g}$ & 0 & 85 & $264 \cdot 3$ & I 7 I 8 & 0.65 & 0.03 \\
\hline & 12 & $30-35 \mathrm{~g}$ & 550 & 85 & 285.5 & $172 \cdot 6$ & 0.69 & 0.09 \\
\hline
\end{tabular}

In all experiments the results were tested one-sided, except for Expts I $(a)$ and $(b)$ which were tested two-sided.

$$
\text { * } P<0.005 \text {. }
$$

Table 3. Number of individual animals shown to have Salmonella typhi-murium present in spleen, liver and intestinal tract of groups of ten rats given orally either $275 \mathrm{mg}$ oxytetracycline/ $\mathrm{kg}$ diet for $6, \mathrm{I} 4,22,34$ and 46 weeks or $55^{\circ} \mathrm{mg}$ oxytetracycline/ $\mathrm{kg}$ diet for 24 weeks compared with control groups given o mg oxytetracycline for the same periods of time. Examination made 4 and $8 h$ after an oral inoculation with $10^{8}$ organisms

\begin{tabular}{|c|c|c|c|c|c|c|c|c|c|c|c|c|c|}
\hline \multirow{3}{*}{$\begin{array}{c}\text { Time after } \\
\text { inoculation }(b)\end{array}$} & \multirow[b]{3}{*}{ Sample } & \multicolumn{10}{|c|}{$275 \mathrm{mg}$ oxytetracycline $/ \mathrm{kg}$ diet } & \multirow{2}{*}{\multicolumn{2}{|c|}{$\begin{array}{c}550 \mathrm{mg} \\
\text { oxytetracycline/ } \\
\mathrm{kg} \text { diet } \\
24 \text { weeks }\end{array}$}} \\
\hline & & \multicolumn{2}{|c|}{6 weeks } & \multicolumn{2}{|c|}{ I4 weeks } & \multicolumn{2}{|c|}{22 weeks } & \multicolumn{2}{|c|}{34 weeks } & \multicolumn{2}{|c|}{46 weeks } & & \\
\hline & & $\mathrm{T}$ & $\mathrm{C}$ & $\mathrm{T}$ & $\overrightarrow{\mathrm{C}}$ & $\mathrm{T}$ & $\mathrm{C}$ & $\mathrm{T}$ & $\mathrm{C}$ & $\mathrm{T}$ & $\vec{C}$ & $\mathrm{~T}$ & $\mathrm{C}$ \\
\hline 4 & Spleen & 0 & $\circ$ & 0 & I & 3 & $\mathbf{I}$ & I & I & 3 & I & o & I \\
\hline & Liver & 2 & 3 & 0 & 3 & 4 & 2 & 0 & I & 3 & I & 2 & 2 \\
\hline & Intestinal tract & Io & Io & 10 & IO & ro & 10 & Io & Io & 10 & Io & Io & Io \\
\hline 8 & Spleen & 2 & 3 & 2 & 0 & $\mathbf{I}$ & $\circ$ & 0 & 3 & I & $\circ$ & o & 0 \\
\hline & Liver & 2 & 3 & 3 & 0 & I & 0 & 0 & 3 & $\circ$ & 0 & I & 0 \\
\hline & Intestinal tract & IO & IO & ro & To & Io & 10 & Io & Io & 10 & Io & Io & Io \\
\hline
\end{tabular}

$T$, treated animals; $C$, untreated animals. 
of animals without a history of daily handling during the first 3 weeks. There were no overt signs of disease.

Expts 10-14 (groups to which therapeutic levels of oxytetracycline $\left(275 \mathrm{mg} / \mathrm{kg}\right.$ and $55^{\circ}$ $\mathrm{mg} / \mathrm{kg}$ ) were administered). No growth-promoting effect was observed with a level of either 275 or $550 \mathrm{mg} / \mathrm{kg}$ oxytetracycline. No statistically significant differences were observed in the weights of the tissues of the intestinal tract in Expt $12(275 \mathrm{mg} / \mathrm{kg}$ oxytetracycline for 91 weeks) or Expt $14\left(55^{\circ} \mathrm{mg} / \mathrm{kg}\right.$ oxytetracycline for 85 weeks). In Expt I2 a statistically significant decrease in the weight of the mesenteric lymph nodes was observed after oxytetracycline feeding.

No significant change in the intestinal wall was established by histometrical analysis in Expt 12 (rats given $275 \mathrm{mg} / \mathrm{kg}$ oxytetracycline for 9r weeks).

\section{Bacteriological examination}

No difference in invasive capacity of Salmonella between oxytetracycline-fed and control rats was observed in Expts 7-1 I and 13, in which therapeutic levels of oxytetracycline $\left(275\right.$ and $55^{\circ} \mathrm{mg} / \mathrm{kg}$ ) were administered to the animals (see Table 3 ).

\section{DISCUSSION}

Oxytetracycline had no growth-promoting effect in the conventional rat used in this study; therefore, on this basis, the suitability of the experimental model may be doubted. Another criterion might have been the decrease in the weight of the small intestine after antibiotic treatment (Groth, I961). However, with none of the dose levels used was this phenomenon observed.

No changes were observed in the distribution of the tissue elements within the gut wall of rats given a therapeutic level of antibiotic. This is in contrast to observations made by Jukes, Hill \& Branion (1956), who observed a decrease in the lamina propria in chickens fed on unspecified levels of oxytetracycline or penicillin. Similar observations were made in the germ-free rat (Gordon \& Bruckner-Kardoss, I961).

The decrease in the wet weight of the mesenteric lymph nodes is in accordance with observations in germ-free animals. From these results it may be concluded that antibiotic treatment caused alterations in the small intestine and in the associated lymphoid tissue, which might be consequent on a change in the bacterial flora of the small intestine. It seems reasonable to assume, therefore, that the experimental model was suitable for the study of the effect of antibiotics on the tissue of the small intestine with regard to the possible penetration of Salmonella. It might be postulated that increased susceptibility to invasion by $S$. typhi-murium could occur as a secondary effect following alteration of the intestinal flora by oxytetracycline. It is also possible that the antibiotic exerts a direct action on the enzyme systems of the intestinal epithelial cells or on the phagocytic activity of the reticulo-endothelial system.

From the results of our bacteriological tests it may be concluded that the giving of an antibiotic did not cause a change in the susceptibility to invasion by $S$. typhimurivm since the isolations from the tissues examined were similar in all dietary treatments. These findings are in agreement with those of Sewell \& Nicol (1958), 
who were unable to demonstrate a direct action of "any of a variety of antibiotics, including oxytetracycline, on the phagocytic activity of the reticulo-endothelial system. It should be borne in mind that our studies were performed only in rats given therapeutic levels ( 275 and $55^{\circ} \mathrm{mg} / \mathrm{kg}$ diet) of oxytetracycline. However, the fact that similar results were obtained after several different feeding periods suggests that the same effect might have been expected from lower supplements of antibiotics.

We are aware that our model system is only of a limited value, and that the effect of only one antibiotic in one experimental animal has been investigated. However, similar results were obtained in another model system, that is the penicillin-treated mouse (Ruitenberg, Kampclmacher \& Noorle Jansen, 1972b).

It is subject to debate whether the results might be applicable to antibiotic-treated farm animals.

\section{REFERENCES}

Braude, R., Kon, S. K. \& Porter, J. W. G. (1955). Nutr. Abstr. Rev. 23, 473.

Chalkley, H. W. (1943-4). F. natn. Cancer Inst. 4, 47.

Clegg, F. G. (1962). In Antibiotics in Agriculture p. 361 [M. Woodbine, editor]. London: Butterworth. Coates, M. E. (1962). In Antibiotics in Agriculture p. 203 [M. Woodbine, editor]. London: Butterworth. Franti, C. E., Alder, H. E. \& Julian, L. M. (1971). Poult. Sci. 50, 94.

Gordon, H. A. (1960). Am. Y. dig. Dis. 5, 841.

Gordon, H. A. \& Bruckner-Kardoss, E. (I96I). Acta anat. 44, 2 Iо.

Groth, W. (1961). Arch. exp. VetMed. 15, 30.

Guinée, P. A. M., Kampelmacher, E. H., Hofstra, H. \& Keulen, A. van (1964). Zentbl. VetMed. B IT, 728 .

Jukes, H. G., Hill, D. C. \& Branion, H. D. (1956). Poult. Sci. 35, 716.

Romeis, B. (1948). Mikroskopische Technik i5th ed. München: Leibnitz Verlag.

Ruitenberg, E. J., Guinée, P. A. M., Kruyt, B. C. \& Berkvens, J. M. (1971). Br. J. exp. Path. 52, 192.

Ruitenberg, E. J., Kampelmacher, E. H. \& Noorle Jansen, L, M, van (1972a). Zentbl. Bakt. ParasitKde (Abt. I. Orig. A) $219,336$.

Ruitenberg, E. J., Kampelmacher, E. H. \& Noorle Jansen, L. M. van (1972b). Zentbl. VetMed. B r9, 666.

Sewell, I. A. \& Nicol, T. (1958). Nature, Lond. I8I, I662.

Strehler, B. L., Mark, D. D., Mildvan, A. S. \& Gee, M. V. (r959). F. Geront. 14, 430.

Tangl, H. (1964). Wien. tierü̈rstl. Mschr. 5r, 734 . 